\title{
QUATERNARY GEOLOGY, GEOMORPHOLOGY AND TECTONICS IN THE OGOSTA RIVER VALLEY SYSTEM, THE DANUBIAN PLAIN (BULGARIA) D. ANGELOVA'
}

\section{ABSTRACT}

The Quaternary in the Ogosta River valley system (the Danubian plain) is represented by various genetic types of continental Quaternary sediments (eolian, alluvial, deluvial, proluvial). They lie on a diverse pre-Quaternary base. It is uneven and with various denudation. The accepted correlation schemes are based on local data in which the tectonic factor and duration of deformation have not been accounted for. The present work considers the complex results obtained during the investigation of the Quaternary sediments and formations.

The filling consists of clayey-sandy or calcareous-sandy materials, coloured in rusty nuances by iron hydroxides. Their age has been determined on the basis of the found fauna: Elephas meridionalis Nesti, Anancus arvernensis Cr. et Gob (Bakalov, Nikolov, 1962).

KEY WORDS: Quaternary geology, geomorphology, tectonics, lithology

\section{INTRODUCTION}

The Quaternary in the Ogosta River watershed is represented by various genetic types of Quaternary sediments (Fig. 1). They overlie either a diverse pre-Quaternary base, which is uneven and with various denudation, or a differing in age weathered crust. The thickness of the Quaternary sediments varies from several $\mathrm{m}$ to $110 \mathrm{~m}$. They have been the topic of investigation of many authors (Filipov et al., 1989 and others). Most of the reference literature considers the loess and the loess complex. Regardless of the significant number of works on the Quaternary, the problems concerning its range, genesis, age and correlations are still debatable. The eolian theory about loess origin is accepted in Bulgaria. The present work shows a part of the complex investigations and results obtained during the study of the Quaternary in the Ogosta River watershed in the Danubian plain (Fig. 2 ), in which the author has taken part too.

\section{QUATERNARY GEOLOGY AND GEOMORPHOLOGY}

The Quaternary is represented by different lithological varieties, building different morphological bodies and complexes (Fig. 1). They are grouped as follows: Covering Gravel Formation, Red Clay Formation, Group of Eolian Sediments and Formations (loess complex), Group of Alluvial Sediments (terrace complexes), eluvium, deluvium, gravitational formations.

Covering Gravel Formation. The polygenic gravel with sandy-clayey filler, covering the ridges between the valleys is included in this formation. It is observed at the surface in the form of single spots or strips of different shape (Fig. 1). The gravel is widely distributed and has a considerable thickness from $10-15 \mathrm{~m}$ in the southern parts of the investigated region to $1 \mathrm{~m}$ in the vicinity of the Danube River. The thickness is variable in west-east direction too. This is due to the intensity of the neotectonic movements and to the specific features in the development of the river-ravine network (Vaptsarov et al., 1993, Angelova et al., 2000). They overlie the Neogene sediments with abrupt, uneven and eroded contact. The gravel is not cemented, unsorted, with various piece sizes and diverse composition and processing of the material.

According to their origin these are alluvial-proluvial and alluvial deposits, building two morphological levels at a height of $90-100 \mathrm{~m}$ and $130-150 \mathrm{~m}$ above the contemporary riverbeds.

Red Clay Formation. It is observed at the surface as narrow strips (Fig. 1)in the right valley slopes. The red calcareous-sandy aleurite clays refer to this formation. In most of the cases they are situated between the coarseclastic sediments of the Covering Gravel Formation and the loess complex.

They are uniformly distributed and have been formed under conditions of warm and humid climate. The clays are dense, thick, heavy, unstructured, with massive outlook without expressed stratification. Their bulk 


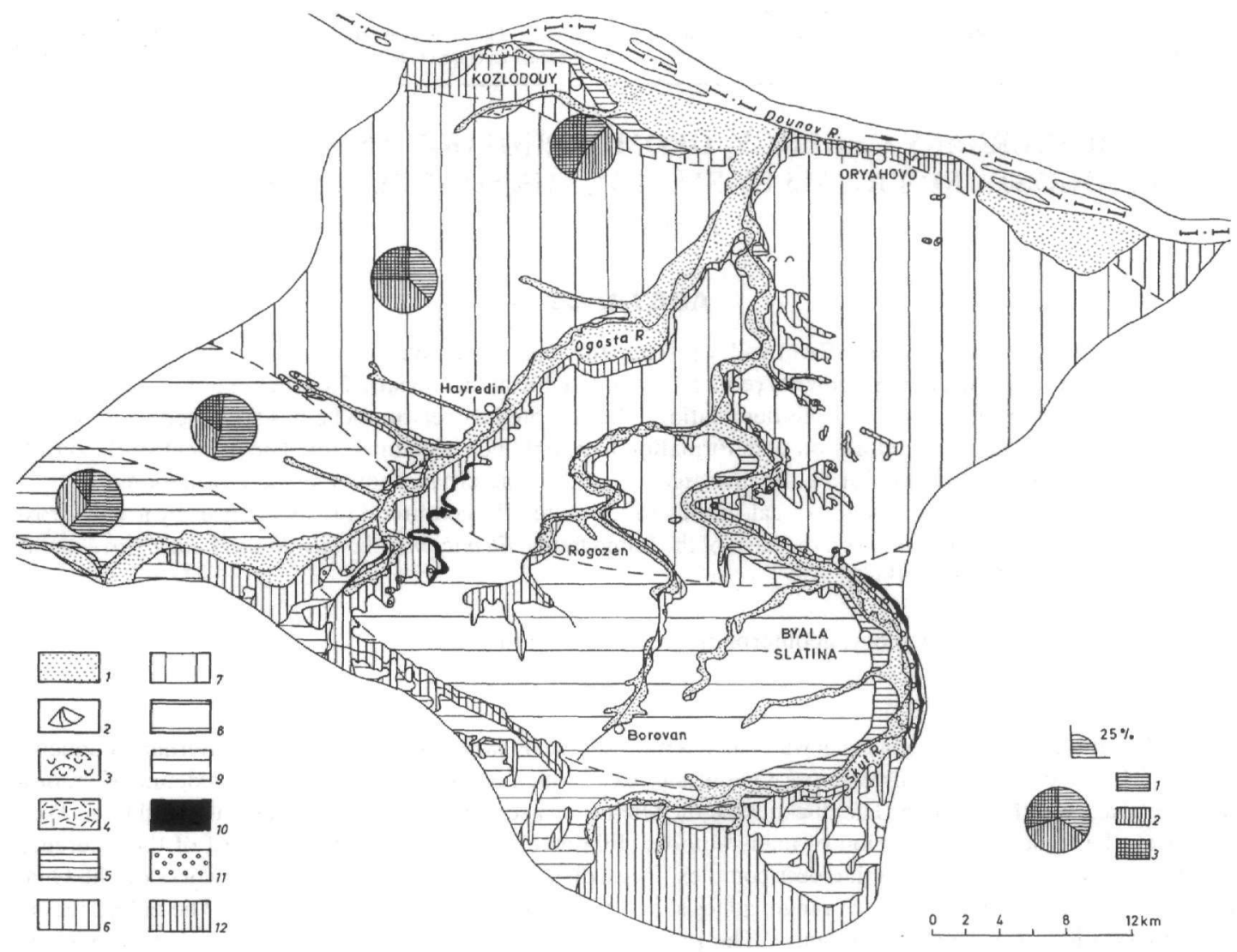

Fig. 1. Geological map of the Quaternary sediments in the watershed of the Ogosta River in the Danubian Plain (according to the Geological Map of Bulgaria in Scale 1:100000, map sheets Kozloduy and Byala Slatina, authors: Filipov et al., 1989 and 1993, with amendments): 1-4 - Holocene: 1 - alluvium; 2 - proluvium; 3 gravitation formations and sediments; 4 - deluvium; 5-9 Pleistocene: 5 - alluvium covered by loess; 6 - sandy loess; 7 - typical loess; 8 - clayey loess; 9 - loess-like clay; 10-11 - Plio-Pleistocene: 10 - Red Clay Formation; 11 Gravel Cover Formation; 12 - pre-Quaternary rock complexes. The circular diagrams show the clay:aleurite:sand ratio (\%) in the loess varieties.

density varies from 1.74 to $2.27 \mathrm{~g} / \mathrm{cm}^{3}$, the porosity reaches up to $20-30 \%$ and the magnetic susceptibility - from 0 to $200 \times 10^{-6} \mathrm{SI}$. They have high carbonate content - within the range of 10 to $50 \%$ of the total rock mass. The thickness of the red clays is not constant and changes from 1-2 $\mathrm{m}$ in the southern parts of the region to $21 \mathrm{~m}$ to the north. The ratio between the building components is simultaneously changed from "clay : aleurite : sand" $=40$ 50:10-20:5-25\% in the northern parts to 50-70: 10-15:2-5\% - $\mathrm{n}$ the southern parts. The age, as well as the origin of the red clays in Bulgaria are debatable problems (Fig. 3). The author has accepted the eolian-alluvial-proluvial origin as the most suitable one for the investigated territory. This has been confirmed by the pollens found in a borehole at a depth of 24 to $31 \mathrm{~m}$, that refer to the $\mathrm{W}_{2}$ interstadial.

The polens have been determined by M. Dyakova (unpublished data, National Geofund, Sofia), who established in them the predomination of $\mathrm{AP}=88.4-94.4 \%$ (Pinus, Picea, Abies) under the herbaceous $(\mathrm{NAP}=5.6$ $11.4 \%)$ species with Gramineae. The investigated materials are the result of secondary redeposition of the existing at that time paleo-river network.

The red clays were formed under conditions of warm and humid climate on various relief forms (denudation levels, structural steps, river terraces) between 3.3-0.87 Ma (Evlogiev et al., 1995). The redeposition proceeded in connection with the changes in the slopes of the topographic surface to the NE as a result of the neotectonic movements (Angelova et al., 2000). 


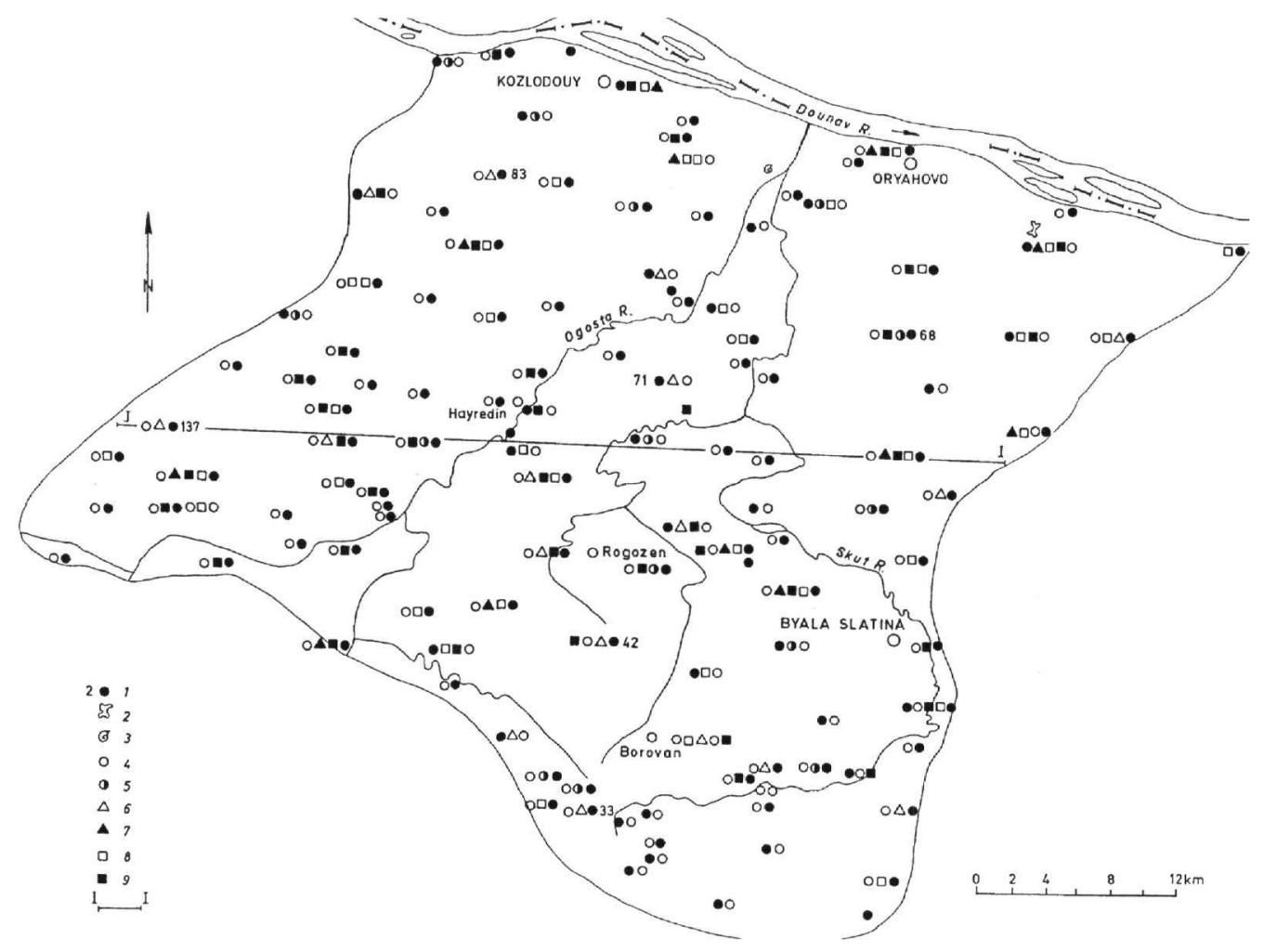

Fig. 2. A map of the actual material: 1 - borehole; 2 - sample with vertebral fauna; 3 - sample with invertebral fauna; 4 - sample with microfauna; 5 - sample for spore-pollen analysis; 6 - sample for physical properties; 7 sample for mineralogical analysis; 8 - sample for granulometric analysis; 9 - sample for sediment-petrographic analysis; 10 - profile line $(I-I)$.

The Group of the Eolian Sediments and Formations includes the loess horizons with the buried soils in them. They have a considerable thickness and are widely distributed in the studied region. Their thickness varies from 1-2 to $110 \mathrm{~m}$. It changes in the same directions as the red clays, which in single cases is also an indication for secondary redeposition of the existing in these times paleoriver network. It has been established from the performed investigations that there are no complete stratigraphic sections. This shows that the correlations made are relative in their essence. There are 5 loess horizons and several secondary redeposited ones in the investigated area. The ratios between clay, aleurite and sand are different and they determine the loess division into: sandy (10-20:40-50:15-20 \%), typical and clayey (50-70:20-30:1-2\%) and loess-like clay (40-60:10-30:5-10\%). The calcium carbonate content is high (20-40\%) and calcareous concretions have been formed in the loess.

The loess density varies from 1.69 to $2.16 \mathrm{~g} / \mathrm{cm}^{3}$, the magnetic susceptibility is from 4 to $929 \times 10^{-6}$ SI for the clayey loess and from 0 to $186 \times 10^{-6}$ SI for the loess-like clays. Teeth and bones of Castor sp. were found in the loess-like clays near the Boukovets village. There about 1 to 5 buried soil horizons in the loess (Fig. 4). Almost all researchers of the region have used them for stratigraphic purposes. According to the author it is difficult to use them for stratigraphic purposes at this stage without additional studies, since it cannot be determined what are the soil horizons of regional importance with spatial homogeneity and established age. Moreover, they are wedgelike and interrupted in immediate proximity in one and the same morphological bodies. The buried soils are calcareous-aleuritic to strongly aleuritic clays and only some of them are very rich in humus. Their density is $1.74-2.22 \mathrm{~g} / \mathrm{cm}^{3}$ and their magnetic susceptibility - from 25 to $250 \times 10^{-6}$ SI. The distribution of the minerals in them is not uniform. The age of the loess complex as a whole is not proved. Bearing fauna and flora specimens are found in it but there are no guide forms. The encountered paleoflora confirms only the Wurmean $\left(\mathrm{W}_{2}\right.$ and $\mathrm{W}_{3}$ ) and Holocene age. 


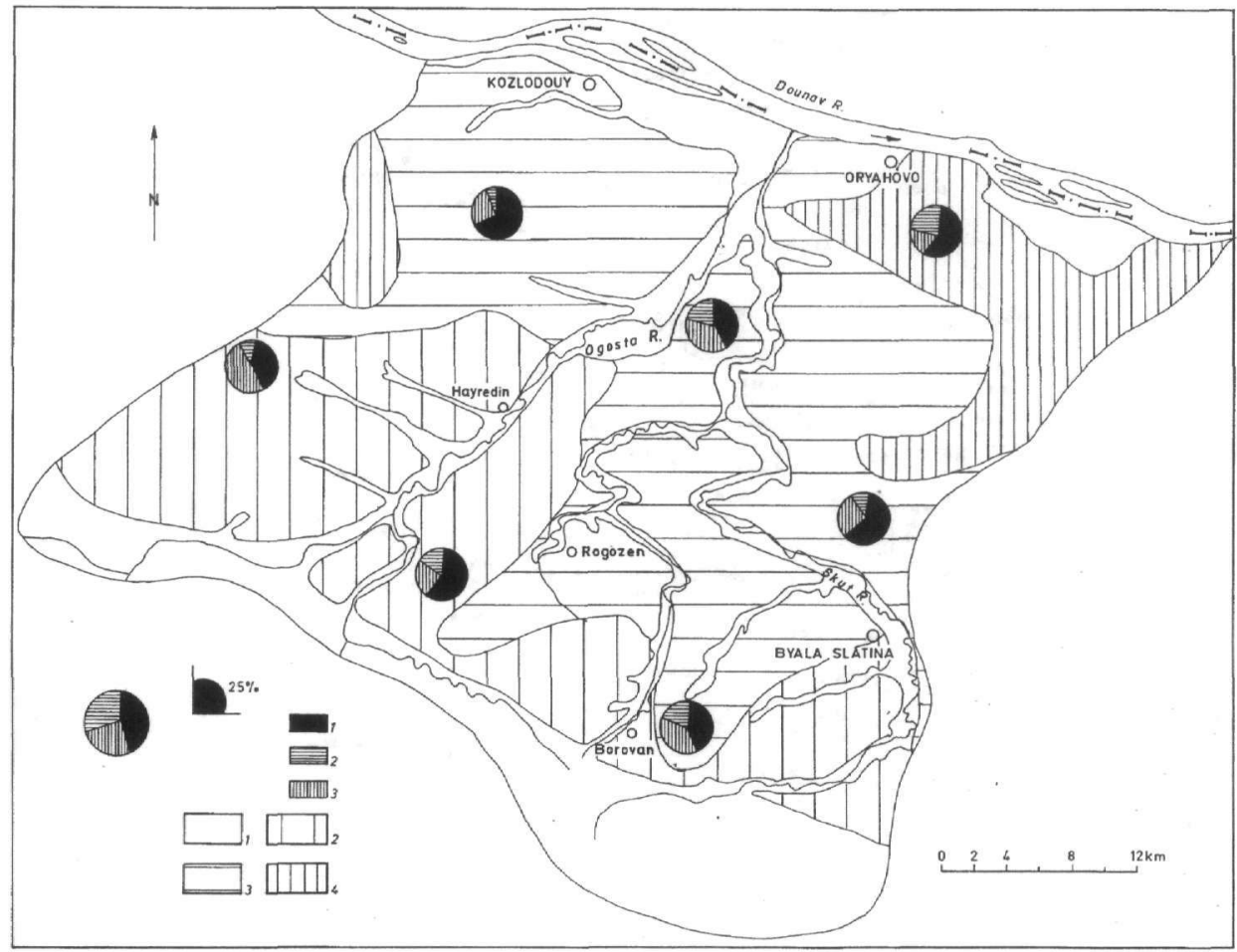

Fig. 3. Map of the distribution and thickness of the red clays: 1 - sections with no red clays; sections with red clay thickness: 2 - 0-5 m, 3 5-10 m, 4 - 10-15 m. The circular diagrams show the clay:aleurite:sand ratio (\%).

The Group of the Alluvial Sediments contains the sediments building the accumulative superstructures of the high, middle high and low flood terraces belonging to the Pleistocene and of the flood Holocene river terraces. The high terraces are very often on different levels and are of relict character. The fifth overflood terrace along the Ogosta River for example is observed at the level of $75-85 \mathrm{~m}, 60-70 \mathrm{~m}$ and $50-60 \mathrm{~m}$. The average high river terraces have medium relative heights: $40-50 \mathrm{~m}$ (for the fourth one), 30-35 m (for the third one), 18-25 m and 8-12 $\mathrm{m}$ above the contemporary riverbeds (for the low overflood terraces). The alluvial sediments are from the riverbed facies and have a thickness from several centimetres to $25-30 \mathrm{~m}$. The gravel has mainly middle- and small-size pieces and is well processed, with different composition and sand filler. The age of the first overflood terrace is proved by the found fauna: Unio pictorum platyrhynshus Rossm, Coretus cerneus L. and Planorbis planorbis L.

The alluvial sediments of the Holocene flood terrace complex comprise the sediments of the riverbed and flood facies building the low and high flood terraces. The alluvium thickness is very variable - from 1 to $40 \mathrm{~m}$. The age is determined according to the found fauna: Theodoxus transversales Pfeif, Lithoglyphus Pfeif, Amphimelania holandri Ferr, Fagita acicularis Ferr. (Kojumdgieva, unpublished data, National geofund).

The eluvial, gravitational and proluvial sediments have the greatest distribution compared to the other genetic types (Fig. 1). Their formation had started before the Holocene and was enhanced during the Holocene and the contemporary stage. The different sub-types of the chernozem soils as well as the coarse mechanogenic eluvium filling the karst forms, are the most widely distributed eluvial sediments. According to their origin they were the result of the mechanical, chemical and biogenic weathering. The eluvium thickness varies between 10$20 \mathrm{~cm}$ and $10 \mathrm{~m}$. It is very thin. The proluvial sediments have a more restricted distribution and their thickness does not exceed $10 \mathrm{~m}$. The gravitation formations are observed mainly along the right river valley slopes. They are of different origin but their composition depends on the rocks building the slopes. These are coarse unsorted materials. Their thickness is usually small $(1-6 \mathrm{~m})$ for the erosion provoked ones and much greater - for the tectonically formed ones. The deluvial deposits in the loess terrains are fine, clayey-sandy ones.

The formation of the contemporary relief in the considered territory is related to the closing and filling with sediments of the Fore-Carpathian basin and the following post-collision extension. Tectonically predetermined 


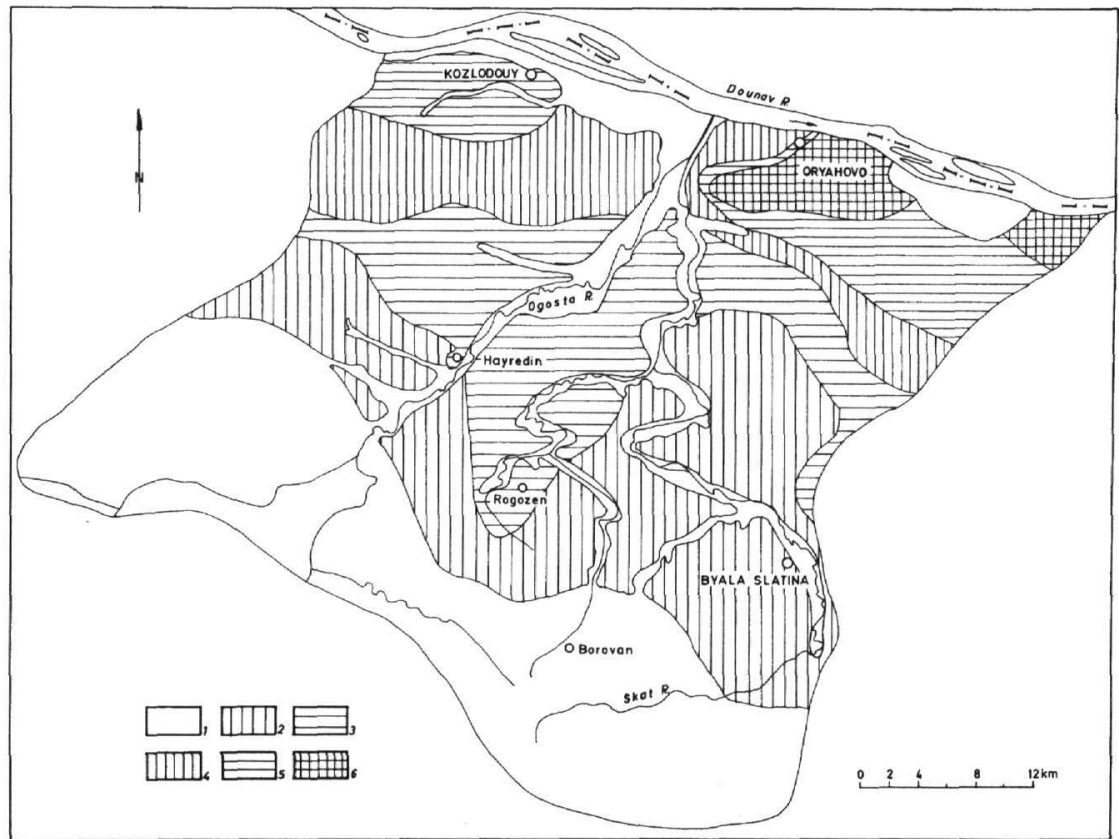

Fig. 4. Map of the distribution and number of the fossil soil horizons in the loess complex: 1 - 0;2 - 1; 3 - 2; 4 $3 ; 5-4 ; 6-5$.

relief is observed: local fold-block forms, gravitation steps, negative structural-denudation lowerings filled and buried by younger sediments, a number of faults predetermining the main directions of the river-valley network. The most pronounced display of the action of the endogenic and exogenic processes is observed in the morphology of the river valleys and the connected with them terrace complexes as well as of the karst forms. The karst is either covered by the loess complex or is observed at the surface. The underground karst is also well presented. The process of young karst formation is connected with the Late Pliocene - Early Quaternary development of the relief. The stages in its development are closely related with the formation and evolution of the river-ravine network. The karstification is an incomplete process and the development of karst forms continues till now. The loess form complex is most widely distributed. It builds the loess accumulative surface. It is strongly dismembered by gullies, dry valleys and ravines (Fig. 5).

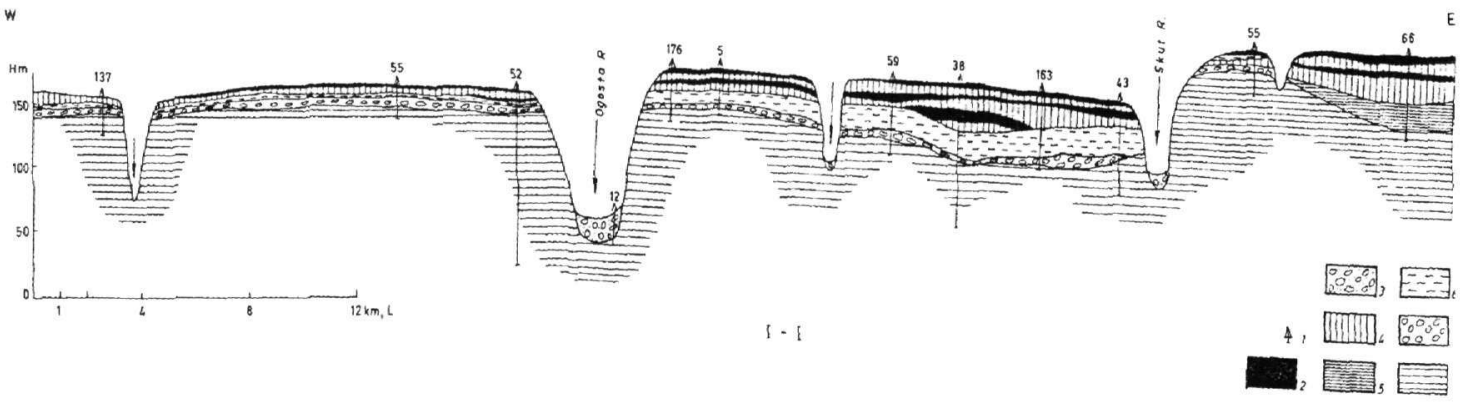

Fig. 5. A generalised geological section of the Quaternary sediments in the watershed of the Ogosta and Skut Rivers in the Danubian Plain along the profile I-I (Fig. 2): 1 - borehole; 2 - soil horizons; 3 - contemporary alluvium; 4 - loess horizons; 5 - clayey loess; 6 - red clays; 7 - gravel cover; 8 - pre-Quaternary rock complexes.

The surface relief in the investigated region is strongly anthropogenic as a result of the economic activity riverbed corrections, microdams, terraced slopes, quarries, dikes, etc. 


\section{QUATERNARY TECTONICS}

The investigated territory comprises parts of the Moezian Microplate (Lom structure) and the Deformed Continental Edge (Angelova et al., 2000). Steps of the block type formed as a result of the listric extensional tectonics are included in the deformed continental edge. The Quaternary tectonic units did not inherit the depression Neogene units. They were controlled by the specific geodynamic processes in the investigated region. The differences between the local tectonic units were realised during the Late Pliocene - Early Quaternary stage, mainly during the Middle Pleistocene and at the Pleistocene-Holocene boundary. The Quaternary vertical tectonic deformations have a total value between $80-100 \mathrm{~m}$ and $120-180 \mathrm{~m}$. The vertical tectonic deformations were reflected in the vertical deformations and outlevellings of the terrace levels. For example, the fifth overflood Ogosta River terrace in the various sections is observed at levels $75-85 \mathrm{~m}, 60-70 \mathrm{~m}$ and $50-60 \mathrm{~m}$. The vertical tectonic movements between it and the fourth overflood terrace are between 10 and $45 \mathrm{~m}$ for the various local morphostructural units. The fourth overflood terrace is on the average at a level of $40-45 \mathrm{~m}$, but in the section near the Hairedin village is at a height of $30-35 \mathrm{~m}$ and reflects the local tectonic subsidence. The tectonic movements realised at the boundary between the fourth and third overflood terraces is of the order of 10-15 m, between the third and second, and the second and first overflood terraces - about 10-12 $\mathrm{m}$. The tectonic movements realised at the Pleistocene-Holocene boundary were very differentiated - between $+7 \mathrm{~m}$ and $-30 \mathrm{~m}$. Tectonic anomalies are observed in some sections too - for example, between the villages of Lehchevo and Kriva Bara, where the alluvial deposits of the second overflood terrace are in tectonic contact with the alluvial deposits of the flood terrace. The horizontal tectonic deformations have a strike-slip fault character. Generally, these are small-amplitude movements along fault structures. They played the control role in the change of the direction of river water movement to the NE towards the erosion basis. For example, the Ogosta River flows along a fault directed to the WE between the Vladimirovo and Gromshin villages, while it abruptly changes its flow direction to the NE to the north of the Gromshin village. The morpho-delineating fault structures are seismo-generating. Earthquakes with $M=2-4$ took place along them in the period 1980-1987. The contemporary vertical movements for the period from 1930 till 1985 are 1.2-2.0 mm/a (Karagjuleva, Shanov, 1990, Vaptsarov et al., 1993, Spiridonov, 1994, Angelova et al., 2000). The tectonic movements at the Holocene-Pleistocene boundary were characterised by great deformations and as a result the Kozloduy local block structure was formed. The total value of the Holocene tectonic movements within its range were from -20 to $-30 \mathrm{~m}$. The contemporary vertical movements here were from -1.2 to $-2.5 \mathrm{~mm} / \mathrm{a}$, calculated for the period from 1930 till 1985 (Spiridonov, 1994, Angelova et al., 2000).

\section{CONCLUSIONS}

The investigated terrain is representative for the geodynamic development of the Moezian Platform (the Lom depression) during the Quaternary and the contemporary stage. Moreover, similar investigations are very necessary especially in connection with the monitoring carried out for the "Kozloduy" Nuclear Power Plant, situated in this area, as well as for other strategic economic enterprises in Bulgaria.

\section{REFERENCES}

ANGELOVA, D. et al. 2000. Geomorphological Maps of Bulgaria in Scale 1:100000 and Explanatory Note to It, Map Sheets Kozloduy and Byala Slatina. Sofia, Ministry of Environment and Water (in press).

BAKALOV, P., NIKOLOV, I., 1962. Tertiary Mamals. The Fossils of Bulgaria, 10. Sofia, 162 pp. (Publ. House of the Bulg. Acad. of Sci.) (in Bulgarian).

EVLOGIEV, J., SHOPOV, V., POPOV, N., 1995. Comparative geomorphological and biostratigraphic investigations of Quaternary continental deposits in Central North Bulgaria. J. Bulg. Geol. Soc., 56, 3, 47-55 (in Bulgarian).

FILIPOV, L. et al. 1989. Geological Maps of Bulgaria in Scale 1:100000 and explanatory notes to them, map sheets Kozloduy and Byala Slatina. Sofia, Committee on Geology and Mineral Resources.

KARAGJULEVA, J., SHANOV, S. 1990. Seismic-Tectonic Assessment. In: NPP “Belene”. Investigation of Standpoints of the Bulg Acad. of Sci., Sofia, Publ. House of the Bulg. Acad. of Sci., 270-283 (in Bulgarian).

SPIRIDONOV, H. 1994. Investigation on the neotectonics and geodynamics of the Moezian Platform. Problems of Geography, 4, 76-87 (in Bulgarian).

VAPTSAROV, I., FILIPOV, L., SOKOLOVA, P., SIMEONOV, J. 1993. Quaternary geomorphology and neotectonics of Central North Bulgaria. Problems of Geography, 3, 18-32 (in Bulgarian). 


\title{
PALAEOMAGNETISM AND MAGNETIC FABRICS OF THE ALMOPIAS, THESSALY AND MILOS VOLCANICS. IMPLICATIONS FOR THE REGIONAL DEFORMATION*
}

\author{
A. ATZEMOGLOU ${ }^{1}$, D. KONDOPOULOU ${ }^{2}$ AND I. ZANANIRI ${ }^{2}$
}

\begin{abstract}
New palaeomagnetic and rock magnetic data obtained from the plio-quaternary volcanics in Almopias (NW Greece) are presented, together with existing ones from two other localities (Thessaly and Milos) in the Aegean extensional area. In most cases a stable component, slightly deviated from the expected direction, has been identified. Rock magnetic analysis reveals the presence of either magnetite (Thessaly), hematite (Milos) or both (Almopias) The anisotropy of magnetic susceptibility reaches significant levels for only part of the samples whereas the anisotropy ellipsoid could be defined in only one case (Almopias).

The existing structural data for the three areas, together with fault plane solutions provide a representative deformation pattern. Comparison of -small- rotation angles and possible rotation of the stress field has been possible in the case of Almopias.
\end{abstract}

KEY WORDS: palaeomagnetism, volcanics, magnetic fabric, rotation, Almopias, Thessaly, Milos, Aegean tectonics.

\section{ПЕРІМНЧН}

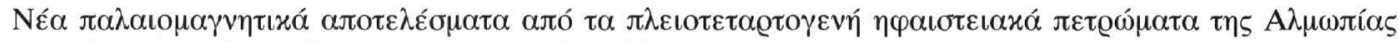

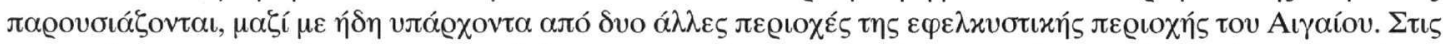

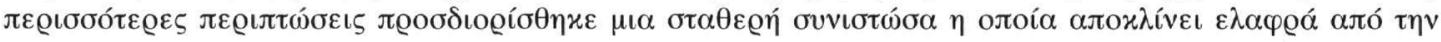

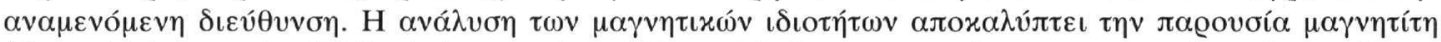

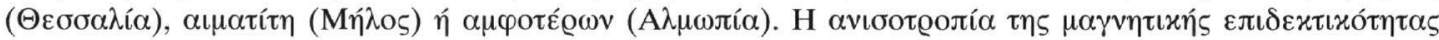

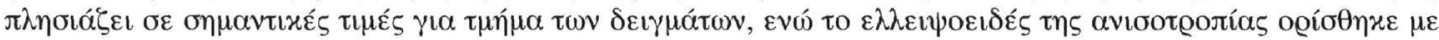

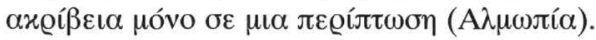

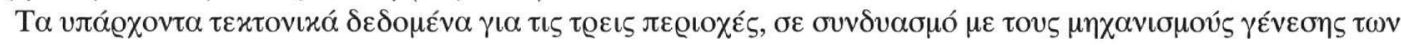

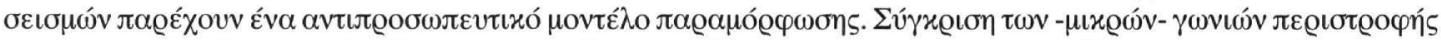

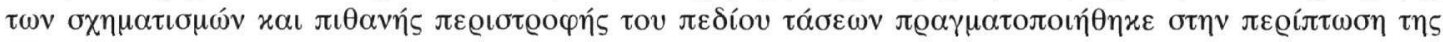
A $\lambda \mu \omega \pi i \alpha .5$.

\section{INTRODUCTION}

Plio-quaternary volcanics outcrop at several places in the broader Aegean province. They are related either to the South Aegean active volcanic arc or to the back-arc extensional area. In all cases, radiometric data and detailed mineralogical studies are available.

The present study focuses at three areas one of which belongs to the Aegean volcanic arc (Milos) whereas the other two are situated further to the North (Thessaly, Almopias). The aim of the study was the careful investigation of the palaeomagnetic and rock magnetic properties of these recent volcanics in order to define stable, reliable directions and eventual rotations. At a second step, an examination of the existing numerous neotectonic and seismological data would allow comparison between these rotations and stress field.

\section{GEOLOGY AND SAMPLING}

The studied formations are spread over a wide area of Greece, in three different geotectonic units: The

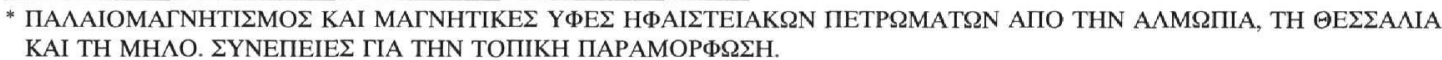

1. IGME, Frangon 1, 54626 THESSALONIKI

2. Aristotle University of Thessaloniki, P.O. Box 352-1, 54006 THESSALONIKI

e-mail: despi@geo.auth.gr 
Vardar zone (Almopias area), the Pelagonian zone (Thessaly) and the Attico-cycladic zone (Milos) (Fig. 1).

Almopias is situated about $130 \mathrm{Km}$ north-west of Thessaloniki, near to Greek-FYROM frontiers and belongs to the Vardar zone. The volcanism was active in the mountainous area during the whole Pliocene. Volcanic centres are lava domes, dome complexes, lava flows and some dykes. In the surrounding area outcrops are volcaniclastics confirming that explosive activity was intense. Volcanic centre alignment and dykes are oriented in N-S to NE-SW directions. The magmatic products belong to calc-alcaline series with the most alkaline being the youngest volcanic products. Ages vary between 1.8 to $4.5 \mathrm{Ma}$ (Kolios et al, 1980). Sites AL (Alexandros), KOU (Koukourou), PA (Papadhia) and SF (Sfines) belong to the SW part of the complex (Upper Pliocene). Sites KFA, BA (Baltatsouko) are in the northen part (Lower Pliocene, Vougioukalakis, 1994)

Table 1: General information and paleomagnetic results from the studied sites.

\begin{tabular}{|c|c|c|c|c|c|c|l|c|}
\hline Site & N & Age $(\mathbf{M a})$ & D & I & $\mathbf{k}$ & $\mathbf{a 9 5}$ & Location & Reference \\
\hline I & 7 & 2.0 & 182.2 & -56.4 & 49.6 & 10.9 & Milos & 1 \\
\hline III & 8 & 2.3 & 167.7 & -54.7 & 31.4 & 12 & Milos & 1 \\
\hline IV & 6 & 2.3 & 156.7 & -62.8 & 198 & 6.5 & Milos & 1 \\
\hline V & 6 & 1.8 & 357.6 & 53 & 20 & 17.7 & Milos & 1 \\
\hline VI & 5 & 0.95 & 176.1 & -32 & 73.5 & 10.7 & Milos & 1 \\
\hline VII & 5 & 0.95 & 163.9 & -42.9 & 58.6 & 12.1 & Milos & 1 \\
\hline VIII & 5 & 1.8 & 158.7 & -42 & 78 & 14 & Milos & 1 \\
\hline MTHB1 & 7 & 1.4 & 196 & -55 & 125 & 4.7 & Thessaly & 2 \\
\hline MTHB2 & 6 & 1.4 & 152 & -66 & 14 & 16.2 & Thessaly & 2 \\
\hline MTHB3 & 5 & 1.4 & 181 & -38 & 17 & 15 & Thessaly & 2 \\
\hline AGH & 7 & 1.4 & 190 & -62 & 374 & 2.7 & Thessaly & 2 \\
\hline AL & 7 & $1.8-1.9$ & 193.2 & -59.6 & 27 & 11 & Almopias & 3 \\
\hline KOU & 12 & $4.3-4.4$ & 6.4 & 62 & 26 & 8.3 & Almopias & 3 \\
\hline KFA & 4 & 4.6 & 11.7 & 51 & 111 & 6.6 & Almopias & 3 \\
\hline SF & 8 & $1.8-1.9$ & 353.1 & 58.8 & 50 & 6.6 & Almopias & 3 \\
\hline PA & 6 & 2.5 & 5.5 & 49 & 26 & 11.1 & Almopias & 3 \\
\hline BA & 9 & 4.6 & 348.5 & 54 & 63 & 5.9 & Almopias & 3 \\
\hline ALM-ALL & $\mathbf{6}$ & $\mathbf{1 . 8 - 4 . 6}$ & $\mathbf{3 . 1}$ & $\mathbf{5 6 . 1}$ & $\mathbf{1 1 2}$ & $\mathbf{5 . 4}$ & Almopias & $\mathbf{3}$ \\
\hline
\end{tabular}

1. Kondopoulou and Pavlides (1990)

2. Kondopoulou and Caputo, (1997)

3. Present study

The broader area of Thessaly-Pilion-Pagasitikos Gulf has been affected, during Early Pliocene to present, by two main normal fault systems (Galanakis et al, 1998). At Thessaly, the NAFS (Nea Anchialos Fault System) is the major tectonic structure, which lies along the prolongation of the North Aegean Trough (NAT) along which oblique-slip and strike-slip motions are recorded from the focal mechanisms. Both structural and seismological data indicate that the NAFS has a pure dip-slip normal structure (Caputo, 1996). According to available data, NAFS had been active throughout quaternary and is still active up to present. The volcanics (basaltic lava flows), sampled for this study, were dated at $1.4 \pm 0.1 \mathrm{Ma}$ (Innocenti et al, 1979).

Milos Island is situated in the central-western part of the Hellenic volcanic arc, which extends from East (Nisyros, Kos) through Santorini and Milos, to west (Methana, Aegina, Krommyonia). According to Fytikas et al (1986), the calcaline volcanism began during the early Pliocene (5 Ma), while the submarine volcanic activity of Milos began during the middle Pliocene (3.5-2 Ma). The oldest volcanic products consist of tuffs, pumice, ignimbrites, andesitic and rhyolitic lava domes and flows, pyroclastics and lahars. The most recent eruptional products are mainly rhyolites. The main faults are E-W in strike and secondly NW-SE. The oldest formations are metamorphic rocks of the crystalline basement.

Drilled cores and oriented samples have been collected from the three areas on the basis of access facility and freshness of materials. A total of 150 cores have been measured and 113 have been demagnetised (stepwise thermally and by AF techniques). Measurements have been done in the laboratories of Thessaloniki, Strasbourg, Utrecht and Paris. 


\section{RESULTS}

Almopias: 6 sites have been sampled in the Almopias volcanic formations. A total of 80 cylindrical specimens have been measured with a Molspin magnetometer among which 46 have been demagnetized by stepwise heating as well as AF demagnetization. Thermal process was done in ENS (Paris) and in the laboratory of the university of Strasbourg (EOST) and AF in Thessaloniki. In almost all cases, the demagnetization with an AF shielded demagnetizer was not successful because an important amount of NRM remained after the highest capacity was reached by the instrument (about $95 \mathrm{mT}$ ). Demagnetization procedure by stepwise heating up to temperature ranges of $500^{\circ}$ to $630 \mathrm{C}^{\circ}$ was more satisfactory because a stable component could be defined and destroyed.

Thessaly: The NRM values are sufficiently high ranging from 15 to $800 \mathrm{~mA} / \mathrm{m}$. The AF demagnetization procedure was efficient in about $50 \%$ of the cases. During thermal demagnetization (heating up to temperature ranges of $450-685^{\circ} \mathrm{C}$ ), a stable component, directed to the origin, could be defined. Thermomagnetic curves were obtained displaying Curie temperatures below $600^{\circ} \mathrm{C}$. This, combined to the maximum unblocking temperatures observed during thermal demagnetization (about $600^{\circ} \mathrm{C}$ ), leads to the conclusion that the main magnetic carrier is magnetite. The factor of anisotropy of magnetic susceptibility varies from $0.6 \%-5.4 \%$. (Kondopoulou \& Caputo, 1997).

Milos: All samples are strongly magnetized with NRM intensities ranging between 50 and $4500 \mathrm{~mA} / \mathrm{m}$. AF demagnetization on pilot samples was inefficient as half of the initial magnetization remain after applying a field of $95 \mathrm{mT}$. Well-defined directions were obtained when the samples were stepwise heated between $25^{\circ}$ and $550^{\circ} \mathrm{C}$. Details on these results can be found in Kondopoulou and Pavlides (1990).

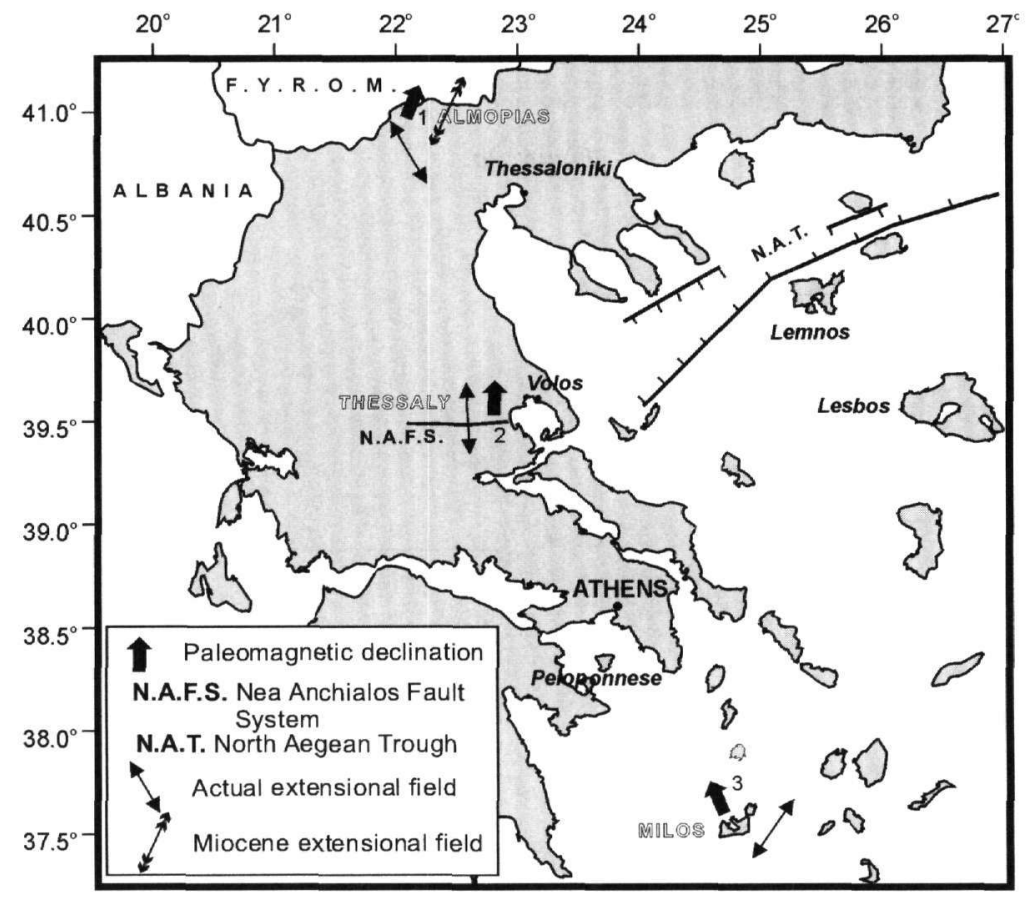

Figure 1. Location of studied areas, palaeomagnetic directions and stress fields.

Site SF. In most cases, a small viscous component and a stable one directed to the origin have been defined. The maximum unblocking temperature $\left(630^{\circ} \mathrm{C}\right)$ observed during thermal demagnetization leads to the conclusion that the rocks of this site contain mainly hematite.

Site BA. We generally observe a stable component directed to the origin and rarely a small viscous one. The samples are demagnetized at temperatures up to $585^{\circ} \mathrm{C}$ and alternating fields up to $60 \mathrm{mT}$, therefore magnetite is the main magnetic carrier.

Site PA. Some samples are quickly demagnetized in fields up to $30 \mathrm{mT}$ while others are not fully demagnetized in higher fields $(80 \mathrm{mT})$. In all cases, a viscous and a primary component are well defined. The dominant 

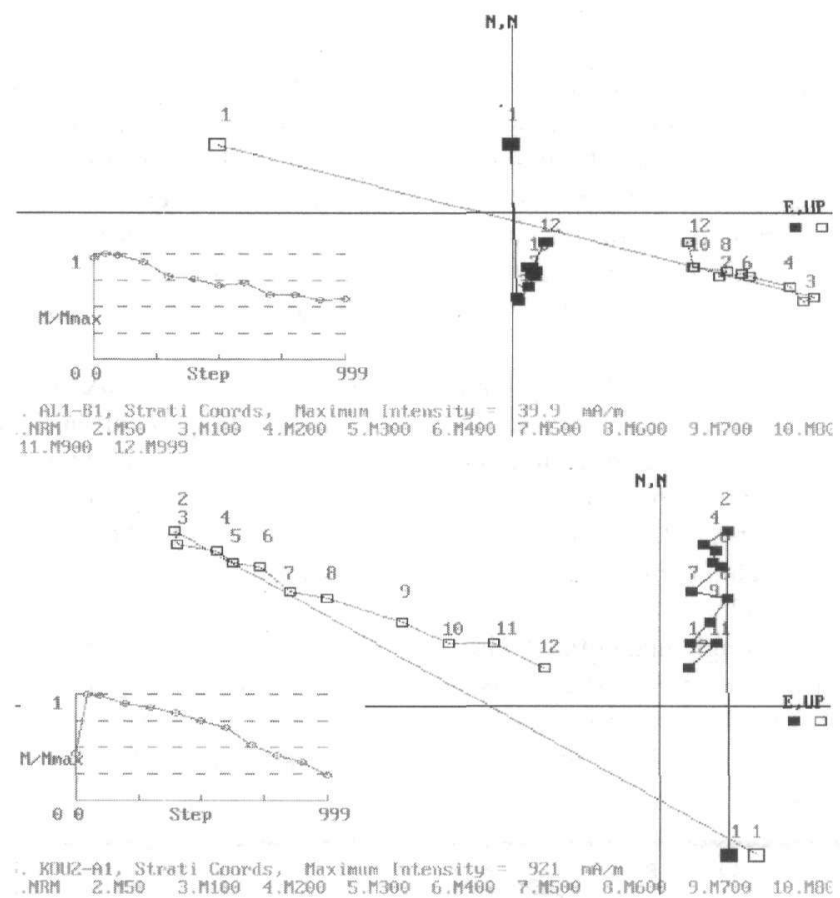

Figure 2a.
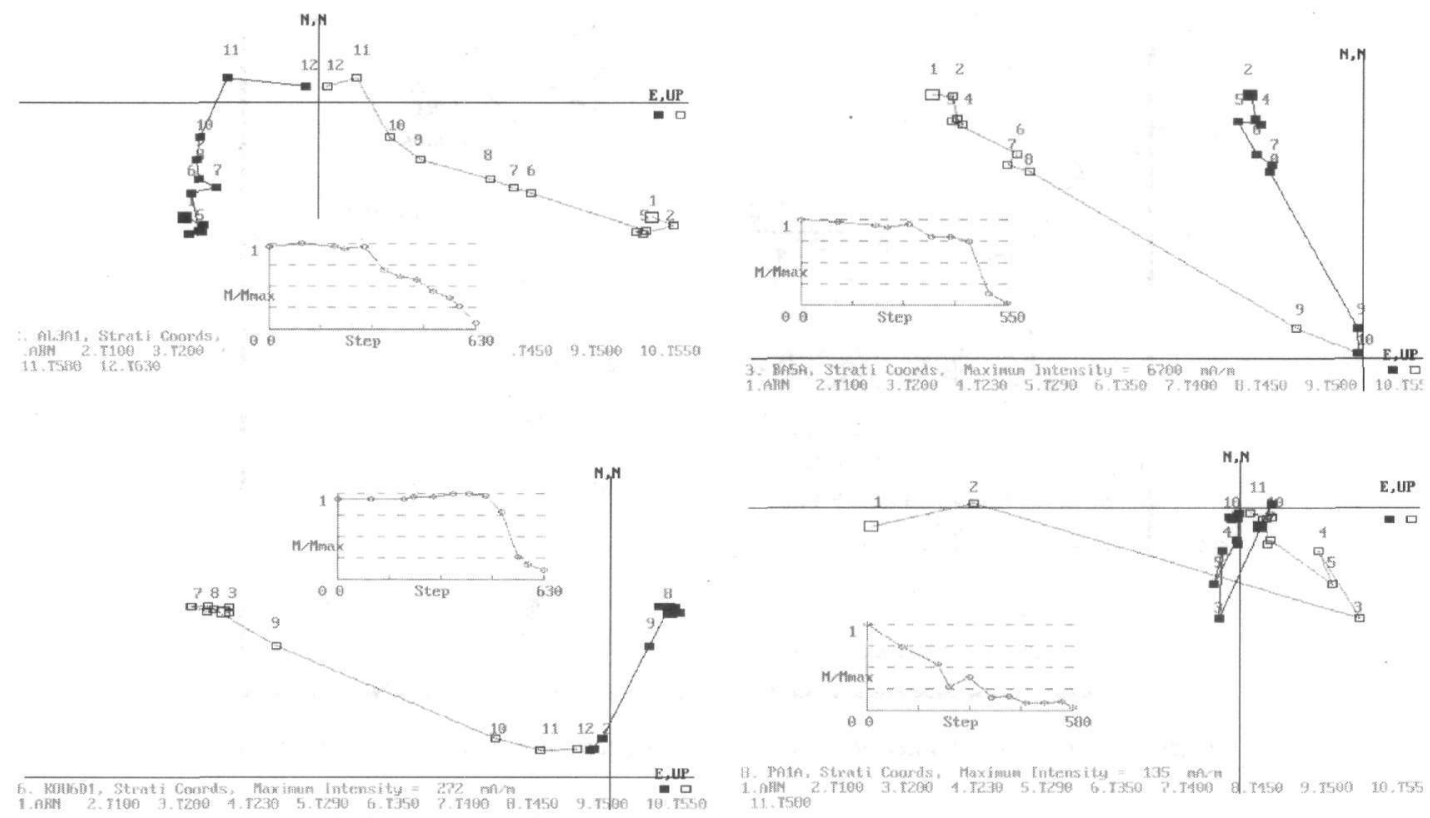

Figure $2 b$.

Figure 2(a,b): Typical analysis of palaeomagnetic directions and decay curves for representative samples.

magnetic mineral is magnetite.

Site AL. Using both AF and thermal techniques, two components are isolated, a strong viscous with stable direction and a primary one. Magnetite is the main magnetic carrier.

Site KOU. Same as site AL. Two components have been registered: a viscous and a primary one directed to 

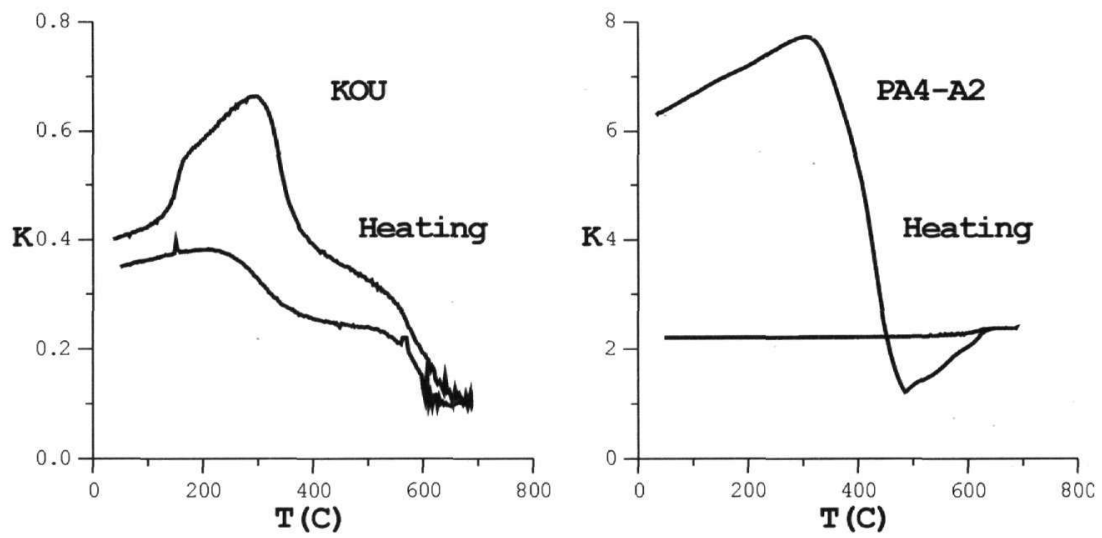

Figure 3: Representative thermomagnetic curves of Almopias volcanic samples, showing the magnetic susceptibility, $K$, changes with temperature.

IRM

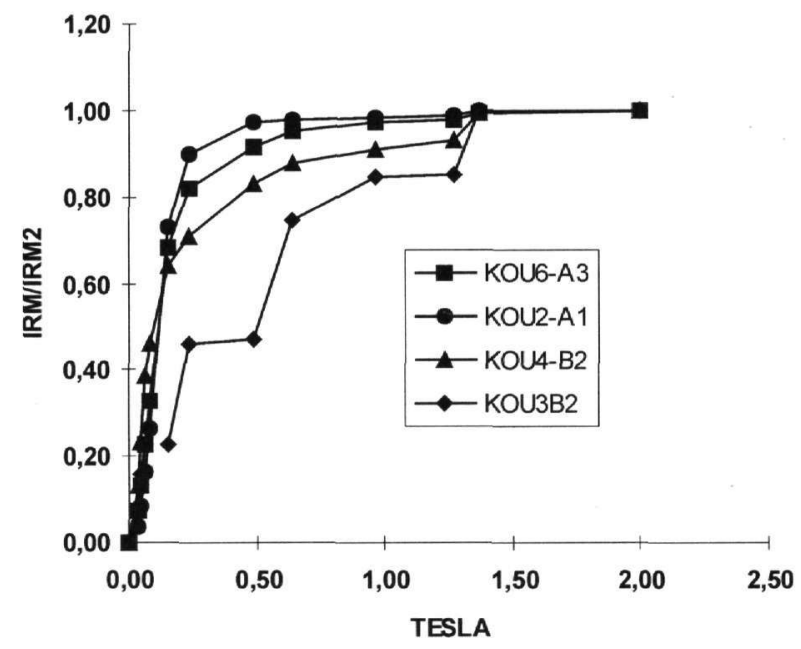

Figure 4: Isothermal remanent magnetization curves for site $\mathrm{KOU}$.

the origin. In four cases magnetite and in most other cases hematite are the carriers of magnetization.

\section{ANISOTROPY OF MAGNETIC SUSCEPTIBILITY.}

By applying the method of anisotropy of magnetic susceptibility (AMS) on rock samples several parameters -scalar and directional- arise (Zananiri, 2001 and references therein). The AMS measurements were performed using the KLY-2 Kappabridge (Geofysica, Brno) equipment at the University Paul-Sabatier, of Toulouse (France). The most important ones are examined.

The bulk magnetic susceptibility magnitude, $\mathrm{K}_{\mathrm{m}}=1 / 3\left(\mathrm{~K}_{1}+\mathrm{K}_{2}+\mathrm{K}_{3}\right)$, varies from $196.49 \times 10^{-6}$ SI to $26795.95 \times 10^{-6} \mathrm{SI}$, with a mean value of $14161.00 \times 10^{-6} \mathrm{SI}$. This, generally, high susceptibility can be attributed to the presence of magnetite, which is confirmed by thermomagnetic analysis (figures $3 \mathrm{a} \& 3 \mathrm{~b}$ ) and microscopic examination of thin sections.

The anisotropy degree, $\mathrm{P}=\mathrm{K}_{1} / \mathrm{K}_{3}$, ranges, in the studied samples, from 1.001 to 1.065 - average of 1.028 , that is $2.8 \%$. Those values are quite low, however they are expected for the case of volcanic rocks.

The variation plot of Jelinek (1981) of AMS anisotropy degree versus bulk magnetic susceptibility (Fig.5a) shows that the anisotropy degree remains quite constant and there is no obvious correlation with the magnetic susceptibility magnitude. 


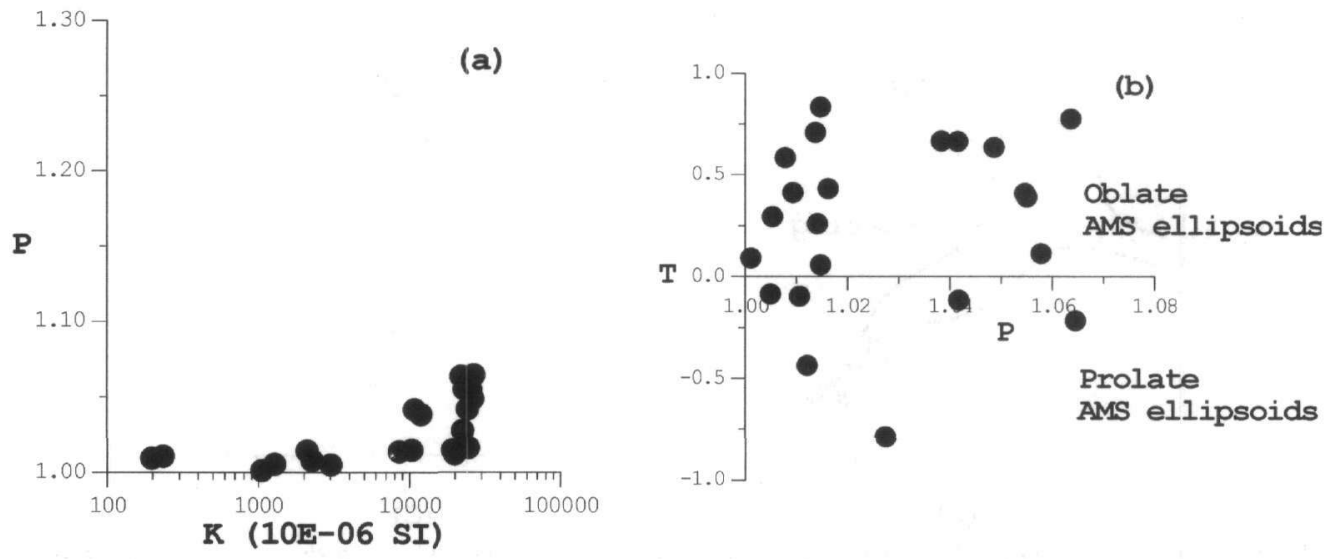

Figure 5: (a) Anisotropy degree (P) versus magnetic susceptibility (K) plot; (b) Variation plot of Jelinek (1981) AMS anisotropy parameter $(T)$ and anisotropy degree $(P)$.

Finally (fig. $5 b)$, the shape parameter $T=\frac{2\left(\ln K_{2}-\ln K_{3}\right)}{\ln K_{1}-\ln K_{3}}-1$, exhibits great variation, but changes irrespective of the anisotropy degree. The majority of the samples lie in the $\mathrm{T}>0$ domain, implying an oblate shape of the AMS ellipsoid.

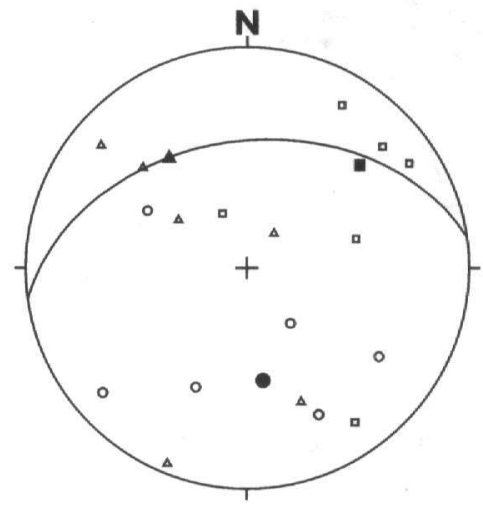

Figure 6: Lower-hemisphere stereoplot of $A M S$ fabrics (squares $=K_{1}$ axes, triangles $=K_{2}$ axes, circles $=K_{3}$ axes).

Considering the orientation of the principal axes of the magnetic susceptibility ellipsoid, in most of the sites they are quite well-clustered. Their mean values for the Almopias region are $\mathrm{K}_{1}=47 / 31, \mathrm{~K}_{2}=325 / 38, \mathrm{~K}_{3}=172 / 48$ (Fig.6).

\section{DISCUSSION AND CONCLUSIONS}

The majority of the studied samples have displayed a coherent behavior during palaeomagnetic processes. Stable components have been isolated and their primary character confirmed by the existence of both normal and reverse polarities. These directions are directed either N-S (Thessaly) or are slightly deviated (Milos, Almopias). Inclinations significantly lower than the expected have been observed only in few sites of Milos that are situated in the main depression (graben) of the island. In all other cases, I values are averaged around the expected ones. The slight counterclockwise rotation of Milos $\left(\sim 11^{\circ}\right)$ is in good agreement with palaeomagnetic results obtained in Naxos, Rhodes, Kassos and Crete (Duermeijer et al., 2000) and suggests a possible connection of the island with the central-eastern Aegean "bloc" which is probably coupled to the westward moving Anatolia. Nevertheless, this small rotation is not supported by the rotation of the stress field which id directed NE-SW as inferred by earthquake focal mechanisms (Louvari, 2000) and appears as constant at least since Pliocene (Kondopoulou and Pavlides, 1990 and references therein). 
The absence of rotation in the Thessaly volcanics (Kissel et al, 1986; Kondopoulou and Caputo, 1997) confirms that no strike-slip motion could be in the origin of the deformation which is taken up by dip-slip normal faulting. Therefore the movement of the older E-W dextral fault, formed in Miocene times (Mountrakis et al, 1993) seems to be totally replaced by the two normal re-activations suggested by the previous authors.

The new results from Almopias do not indicate a rotation for these volcanics $\left(D=3^{\circ}\right)$. Nevertheless previously obtained data from different parts of the complex had shown an about 15 to $17^{\circ}$ clockwise rotation (Bobier, 1968; Kondopoulou and Lauer, 1984). When combined, the three sets of data yield a mean value of $\mathrm{D}=10.7^{\circ}$ and $\mathrm{I}=58.8^{\circ}$, indicating a small clockwise rotation which is supported by the counterclockwise rotation of the stress field between Miocene and Quaternary (Pavlides, 1998, fig.1).

The existence of important geothermal fields in two of the studied areas (Milos and Almopias) could be partly connected to the absence of important rotations. A similar case has been observed in Italy (Baldi et al, 1995), where in an extensional geothermal province (Tuscan, Latium) the inferred continuity between the crustal and lithospheric parts, as this is suggested by the weak rotations, allows the persistence of the thermal processes.

\section{ACKNOWLEDGEMENTS}

We wish to thank V. Spatharas for his help in obtaining the magnetic mineralogy data. Part of the Almopias measurements has been performed in the Paleomagnetism Laboratory of the E.N.S. (Paris) through a bilateral cooperation project (Platon).

\section{REFERENCES}

BALDI, P., BUONASORTE, G., MATTEI, M., FUNICIELLO, R. \& KISSEL, C., 1995. Paleomagnetic evidence of non rotational tectonism in the Tuscan-Latium geothermal province (Italy). Proccedings of the World Geothermal Congress, Florence, Italy, 939-943. Intern. Geoth. Ass., Stanford, USA.

BOBIER, C., 1968. Etude paleomagnetique de quelques formations du complexe volcanique d' Almopias C.R.A.S. (267), 1091-1094.

CAPUTO, R., 1996. The active Nea Anchialos Fault System (Central Greece) : comparison of geological, morphotectonic, archaeological and seismological data. Ann. Geofis., 39, 557-574.

DUERMEIJER, C.E., NYST, M., MEIJER, P.TH., LANGEREIS, C.G., SPAKMAN, W., 2000. Neogene evolution of the Aegean arc : paleomagnetic and geodetic evidence for a rapid and young rotation phase. Earth and Planet. Sci. Let., 176, 509-525.

FYTIKAS, M., INNOCENTI, F., KOLIOS, N., MANETTI, P., MAZZUOLI, R., POLI, G., RITA, F., VILLARI, L., 1986. Volcanology and Petrology of volcanic products from the Island of Milos and neighbouring islets. J. Volcan. Geoth. Res. 28, 297-317.

GALANAKIS, D., PAVLIDES, S., MOUNDRAKIS, D. 1998. Recent brittle tectonic in Almyros-Pagasitikos, Maliakos, N. Euboea \& Pilio. Bulletin of the Geological Society of Greece, vol.XXXII/1, 263-273.

INNOCENTI, F., MANETTI, P., PECCERILLO, A., POLI, G., 1979. Inner arc volcanism in NW Aegean arc: geochemical and geochronological data. N. Jb. Miner. Mh., 4, 145-158.

JELINEK, V., 1981. Characterization of the magnetic fabric of rocks. Tectonophysics 79, T63-T67.

KISSEL, C., LAJ, C., MAZAUD, A., 1986. Paleomagnetic results from Neogene formations in Evia, Skyros and the Volos region and the deformation of Central Aegea. Geophys. Res. Lett., 13: 1446-1449.

KOLIOS, N., INNOCENTI, F., MANETTI, P., PECCERILLO, A., GUILIANI, O., 1980. The Pliocene volcanism of the Voras Mts (Central Macedonia, Greece). Bull. Volcanol., Vol.43-3, 553-568.

KONDOPOULOU, D., LAUER, J.P., 1984. Paleomagnetic data from tertiary units of the North Aegean zone. In J.E.Dixon and A.H.F. Robertson (Editors). The geological evolution of the Eastern Mediterranean. Spec. Publ. Geol. Soc., London, 17, 681-686.

KONDOPOULOU, D., PAVLIDES, S., 1990. Paleomagnetic and neotectonic evidence for different deformation patterns in the South Aegean volcanic arc: the case of Milos island. Proceedings of IESCA, Izmir, 210-223.

KONDOPOULOU, D., CAPUTO, R., 1997. Palaeomagnetic evidence for non-rotational deformation along the Nea Anchialos Fault System, Central Greece. Annali di Geofisica, Vol.XL, N.4.

LOUVARI, E., 2000. A detailed seismotectonic study of the Aegean and surrounding regions, based on focal mechanisms of small earthquakes. PhD Thesis, Univ. of Thessaloniki, 373 p.

MOUNDRAKIS, D., KILIAS, A., PAVLIDES, S., ZOUROS, N., SPYROPOULOS, N., TRANOS, M. AND SOULAKELLIS, N., 1993. Field study of the southern Thessaly highly active fault zone. 2nd Congress Hellenic Geolophysical Union, Florina, 5-7 May 1993, Macedonia, Greece, 603-615. 
PAVLIDES, S., 1998. Dating the neotectonisms in South Almopias (Central Macedonia, N.Greece). Bulletin of the Geological Society of Greece, vol.XXXII/1, 189-197.

VOUGIOUKALAKIS, G. 1994. The Pliocene volcanics of mountain Voras, Central Macedonia, Greece. Bulletin of the Geological Society of Greece, vol. XXX/1, 223-240 (In Greek, abstract in English).

ZANANIRI, I., 2001. The method of anisotropy of magnetic susceptibility: theory and applications. A case study from the Rhodope Massif. $9^{\text {th }}$ Congress of the Hellenic Geological Society (accepted for publication). 